\title{
Effect of Quality Standards in Health Care Services on the Motivation of Employees; An Implementation at Private Hospitals within the Province of Istanbul
}

\author{
Gülay TAMER*
}

\begin{abstract}
Aim: This study aims to evaluate the effect of quality in health standards implemented at health institutions on the motivation of healthcare professionals.

Method: The universe of this study consists of 202 healthcare professionals working at the private Medicana Bahçelievler Hospital operating at European Side of Istanbul with the 898 approval number on the date of 12.03.2019. In this research, the responses of the participants for the questions of the questionnaire were analyzed by the use of AMOS 24.0, and SPSS for Windows 22.00 programs. The subdimensions of quality standards in health care services (QSH), and motivation of employees (ME), being the scales used in the research, were determined by exploratory factor analysis, and then the crosscheck of these dimensions was performed by confirmatory factor analysis. Thereafter, values of Cronbach's alpha, being the reliability coefficient, and composite reliability, and convergence validity were calculated. The effect of quality standards in health care services (QSH) on the motivation of employees (ME) was examined through a structural equation model with implicit variables. And the comparison of all dimensions and subdimensions of the scales of quality standards in health care services (QSH), and motivation of employees (ME) as per demographic attributes was searched by one-way analysis of variance (ANOVA), independent samples t-tests.
\end{abstract}

Results: As a result of the research, it has been observed that the quality standards in healthcare have a significant and positive effect on employee motivation. It was found that the managerial processes dimension of the quality standards in health affects the motivation of the employees in a significant and positive way by using only psychological and social tools, but the use of economic tools and organizational managerial tools among the motivation tools does not affect the motivation of the employee. However, it is seen that quality standards in health do not affect the dimension of educational processes by using psychological and social tools, which are motivational tools, and positively and significantly affect employee motivation by using economic and organizational-managerial tools.

Conclusion: According to the demographic attributes of the participants of the research, it was determined that quality standards in health, and motivation of employees were being affected in a positive direction as their education and experiences increase. It was observed that the increase of the age of employees was positively affecting the managerial processes of quality standards in health, but that it wasn't affecting their motivation. It was determined that the gender of employees wasn't affecting the quality standards in health, and motivation of employees.

Keywords: Health, quality standards, motivation.

Özgün Araştırma Makalesi (Original Research Article)

Geliş / Received: 05.05.2021 \& Kabul / Accepted: 02.09.2021

DOI: https://doi.org/10.38079/igusabder.933163

* Assist. Prof. Dr., Istanbul Gelisim University, Faculty of Health Sciences, Istanbul, Turkey,

E-mail: gtamer@gelisim.edu.tr ORCID https://orcid.org/0000-0002-7897-1603

ETHICAL STATEMENT: The universe of this study consists of 202 healthcare professionals working at the private Medicana Bahçelievler Hospital operating at European Side of Istanbul with the 898 approval number on the date of 12.03.2019. 


\section{Sağlık Hizmetlerinde Kalite Standartlarının Çalışan Motivasyonu Üzerindeki Etkisi; İstanbul İlindeki Özel Hastanelerde Bir Uygulama}

$\ddot{O} \mathbf{z}$

Amaç: Bu çalışma, sağlık kurumlarında uygulanan sağlıkta kalite standartlarının, sağlık çalışanlarının motivasyon düzeyine etkisini değerlendirmeyi amaçlamaktadır.

Yöntem: Bu çalışmanın evreni İstanbul Avrupa yakasında faaliyet gösteren iki özel hastanede çalışan 202 sağlık personelinden oluşmaktadır. 12.03.2019 tarihinde ve 898 onay numarası ile onaylanan bu araştırmada katılımcıların anket sorularına verdiği cevaplar AMOS 24.0 ve SPSS for Windows 22.00 programı desteğiyle analiz edilmiştir. Araştırmada kullanılan ölçekler olan sağlık hizmetlerinde kalite standartları (SKS) ve çalışan motivasyonu (ÇM) ölçeklerinin açımlayıı faktör analizleri ile alt boyutları belirlenmiş, daha sonra ise bu boyutların doğrulayıcı faktör analizi ile sağlaması yapılmıştır. Sonrasında, güvenilirlik katsayısı olan Cronbach's alpha değerleri ve birleşik güvenilirlik ile yakınsama geçerliliği değerleri hesaplanmıştır. Sağlık hizmetlerinde kalite standartlarının (SKS), çalışan motivasyonuna (MTV) etkisi örtük değişkenlerle Yapısal eşitlik modeli ile incelenmiştir. Sağlık hizmetlerinde kalite standartları (SKS) ve çalışan motivasyonu (ÇM) ölçeklerinin toplam ve alt boyutlarının demografik özelliklere göre karşılaştırması ise Tek Yönlü Varyans analizi (ANOVA) ve independent sample-t (bağımsız örneklem t testi) testleri ile araştırılmıştır.

Bulgular: Sağlıkta kalite standartlarının çalışan motivasyonu üzerinde anlamlı ve pozitif şekilde etkilendiği görülmüştür. Sağllkta kalite standartlarının yönetimsel süreçleri boyutunun, çalışan motivasyonunu sadece psikolojik ve sosyal araçlar kullanılarak anlamlı ve pozitif yönde etkilediği ancak motivasyon araçlarından ekonomik araçlar ve örgütsel-yönetsel araçların kullanılmasının çalışan motivasyonunu etkilemediği bulunmuştur. Ancak sağlıkta kalite standartlarının eğitim süreçleri boyutunu, motivasyon araçlarından psikolojik ve sosyal araçlar kullanılarak etkilemediği, çalışan motivasyonu ekonomik ve örgütsel-yönetsel araçlar kullanılarak pozitif ve anlamlı yönde etkilediği görülmektedir.

Sonuç: Araştırmaya katılanların demografik özelliklerine göre; eğitim ve tecrübeleri arttıkça sağlıkta kalite standartlarının ve çalışan motivasyonunun pozitif yönde etkilendiği tespit edilmiştir. Çalışanların yaşlarının artması sağlıkta kalite standartlarının yönetimsel süreçlerini olumlu yönde etkilediği ancak motivasyonlarını etkilemediği görülmüştür. Çalışanların cinsiyetlerinin sağlıkta kalite standartları ve motivasyonlarını etkilemediği tespit edilmiştir.

Anahtar Sözcükler: Sağlık, kalite standartları, motivasyon.

\section{Introduction}

The purpose of quality standards in health is to enable the healthcare organizations to attain their visions and objectives, to increase the motivation and productivity of employees, and to ensure the satisfaction of internal and external customers ${ }^{1}$. In order to have the healthcare organizations attain their planned purposes and objectives by decreasing the failures in health care services provided to patients, continuous improvement and development operations are performed in the direction of quality standards in health ${ }^{2}$. For this reason, the operations for the improvement and development of quality of health care services are continuous ${ }^{3}$. Quality standards in health play an effective role in the formation of an organization's culture, and in the progress of service quality in a systematic process. For the effective implementation of a quality management system at a healthcare organization, it is required to have indicators consisting of concrete, measurable, and substantial data ${ }^{4}$.

Quality in health care services is a process in which the required results are obtained for the patient, and in which the undesirable results don't arise. For this, the efficiency and effectiveness of health care services may be ensured by quality standards in health 5 . Quality standards in health 
(QSH), prepared by the Ministry of Health, are being implemented at all healthcare organizations, and they are also being subjected to inspection and assessment at a specific period by the Ministry of Health ${ }^{6}$. In order to ensure continuity in the effectiveness and efficiency of healthcare organizations, it is required to ensure the motivation of employees ${ }^{7}$. Job satisfaction, organizational commitment, performance, and job fit of the employees, with a high level of motivation, will be high, and the quality will increase, costs will decrease, and satisfaction will increase $^{8}$. In the light of this information, it was examined how the practices actualized for quality standards in health affect the motivation levels of healthcare professionals who directly affect the satisfaction level of patients benefiting from health care services. The result of the research was obtained from two private hospitals being the popular chain hospitals of Istanbul. This research is important for the ones who will make research in this field, and in terms of correct notification of the society. The researchers, who will make research on this subject, may make similar researches at public and private hospitals, and in different regions by using the research's model.

\section{Material and Method}

The universe of this study consists of 202 healthcare professionals working at the private Medicana Bahçelievler Hospital operating at European Side of Istanbul with the 898 approval number on the date of 12.03.2019. Searching the effect of quality standards in health, implemented at healthcare organizations, on the motivation of employees is the purpose of the study. It is being considered that the quality of healthcare services, provided by the healthcare organizations, and meeting the expectations of ones benefiting from health care services are directly related to the motivation levels of healthcare professionals. For this reason, in terms of increasing the quality level of service through more effective and efficient provision of health care services, the motivation levels of healthcare professionals, who are internal customers, directly affect the effectiveness and efficiency of healthcare organizations. The effect of the implementation of quality standards in health on the motivation levels of healthcare professionals, who take part at all the stages of provision of health care services, and who directly affect the satisfaction level of external customers, will be searched, and in this sense, the importance of quality systems and motivation of employees will be revealed.

\section{Results}

For the questionnaire study, the questionnaires of 201 participants were evaluated. The questionnaire was conducted through the distribution of the form to participants at the organization, and then through the collection of the same. Socio-demographic attributes of the participants are provided in Table 1. 
Table 1. Table of percentage distribution of demographic attributes of participants

\begin{tabular}{|c|c|c|c|}
\hline & & $\mathbf{n}$ & $\%$ \\
\hline \multirow{2}{*}{ Gender } & Female & 101 & $50,2 \%$ \\
\hline & Male & 100 & $49,8 \%$ \\
\hline \multirow{5}{*}{ Age Group } & $20-29$ & 54 & $26,9 \%$ \\
\hline & 30-39 & 60 & $29,9 \%$ \\
\hline & $40-49$ & 60 & $29,9 \%$ \\
\hline & $50-59$ & 19 & 9,5\% \\
\hline & $2 \geq 60$ & 8 & "4,0\% \\
\hline \multirow{6}{*}{ Educational Status } & Primary School & 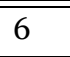 & $3,0 \%$ \\
\hline & Secondary School & 14 & $7,0 \%$ \\
\hline & High School & $\overline{56}$ & $27,9 \%$ \\
\hline & License Degree & 97 & 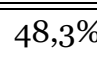 \\
\hline & Postgraduate & 17 & $8,5 \%$ \\
\hline & Doctoral Degree & 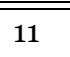 & "5,5\% \\
\hline
\end{tabular}

$50,2 \%$ of the healthcare professionals participating in the research were female, and $49,8 \%$ of them were male. Regarding the distribution of age groups, $26,9 \%$ of them were between ages 20$29,29,9 \%$ of them were between ages $30-39,29,9 \%$ of them were between ages $40-49,9,5 \%$ of them were between ages 50-59, and $4 \%$ of them were of age 60 and above. And regarding their educational statuses, $3 \%$ of them were primary school graduates, $7 \%$ of them were secondary school graduates, $27,9 \%$ of them were high school graduates, $48,3 \%$ of them were license degree graduates, $8,5 \%$ of them were postgraduates, and $5,5 \%$ of them had a doctoral degree (Table 2 ).

Table 2. Table of percentage distribution of participants' profession and experience attributes

\begin{tabular}{|c|c|c|c|}
\hline & & $\mathrm{n}$ & $\%$ \\
\hline \multirow{5}{*}{ Experience } & $<6$ months & 18 & $9,0 \%$ \\
\hline & 6 months -1 year & 30 & $14,9 \%$ \\
\hline & 1-3 years & 77 & $38,3 \%$ \\
\hline & 3-5 years & 50 & $24,9 \%$ \\
\hline & 5-10 years & 26 & $12,9 \%$ \\
\hline \multirow{9}{*}{ Profession } & Nurse & 32 & $15,9 \%$ \\
\hline & Physician & 42 & $20,9 \%$ \\
\hline & Auxiliary Staff & 23 & $11,5 \%$ \\
\hline & Patient Services Staff & 26 & $12,9 \%$ \\
\hline & Executive & 18 & $9,0 \%$ \\
\hline & Pharmacy Staff & 9 & $4,5 \%$ \\
\hline & Cleaning Staff & 5 & $2,5 \%$ \\
\hline & Administrative Staff & 23 & $11, \%$ \\
\hline & Others & 23 & $11,4 \%$ \\
\hline
\end{tabular}


$9 \%$ of the healthcare professionals participating in the research had an experience of fewer than 6 months, $14,9 \%$ of them had an experience between 6 months- 1 year, 38,3\% of them had an experience between 1-3 years, 24,9\% of them had an experience between $3-5$ years, and $12,9 \%$ of them had an experience between 5-10 years. Regarding the distribution of professions of the participants, $15,9 \%$ of them were nurses, $20,9 \%$ of them were physicians, $11,5 \%$ of them were auxiliary staff, $9 \%$ of them were executives, $12,9 \%$ of them were patient services staff, $4,5 \%$ of them were pharmacists, $2,5 \%$ of them were cleaning staff, $11,4 \%$ of them were administrative staff, and $11,4 \%$ of them were other staff.

Accordingly, the statistically significant level is found low by chi-square $\left(x^{2}\right)$ test. In the research model, the model, by which the effects of variables of managerial processes (MP) and educational processes (EP), from among the sub-dimensions of quality standards in health care services (QSH) questionnaire, on the variables of economic means (EM), psychological and social means (PSM) and organization and managerial means (OMM), from among the sub-dimensions of motivation of employees (ME) scale, was searched, was tested. The relationships found to be significant in this model are summarized below;

It was understood that the effect of variable of managerial processes (MP), from among the subdimensions of quality standards in health care services (QSH) scale, only on the variable of psychological and social means (PSM) variable, from among the sub-dimensions of motivation of employees (ME) scale, was positive and significant $(\beta=.142 ; \mathrm{p}<0.05)$. According to this, the increase of the score of managerial processes (MP) variable ensures the increase of the score of only psychological and social means (PSM) dimension from among the sub-dimensions of motivation of employees scale.

The effects of managerial processes (MP) variable on economic means (EM) variable ( $\beta=.052$; $\mathrm{p}>0.05)$, and on organizational and managerial means (OMM) variable $(\beta=.020 ; p>0.05)$ are insignificant.

It was understood that the effect of variable of educational processes (EP), from among the subdimensions of quality standards in health care services (QSH) scale, only on the variable of psychological and social means (PSM) variable, from among the sub-dimensions of motivation of employees (ME) scale, was insignificant $(\beta=0.087 ; \mathrm{p}<0.05)$.

The effects of educational processes (EP) variable on economic means (EM) variable $(\beta=0.294$; $\mathrm{p}>0.05)$, and on organizational and managerial means (OMM) variable $(\beta=0.300 ; p>0.05)$ are positive and significant. According to this, the increase of the score of educational processes (MP) variable ensures the increase of the scores of economic means (EM) dimension, and of organizational and managerial means (OMM) dimension from among the sub-dimensions of motivation of employees scale.

Consequently, the increase of the scores of sub-dimensions of quality standards in the health care services (QSH) scale causes the increase of the scores of dimensions of motivation of employees (ME) scale. In the research made, it was concluded that the high level of the values of all dimensions of QSH was affecting the motivation of employees in positive and significant direction. 


\section{Comparison of Sub-Dimensions of Quality Standards in Health Care Services (QSH), and Motivation of Employees (ME) as per Demographic Attributes}

Independent t-test was used in comparisons with dual categories, and one-way analysis of variance (ANOVA) was used in comparisons with multiple categories. Regarding the variables for which difference was found by ANOVA, the source of difference was examined by the Bonferroni test.

As the comparison of sub-dimensions of quality standards in health care services (QSH), and motivation of employees (ME) as per genders was found to be $\mathrm{p}>0.05$ for all the variables, a significant difference couldn't be determined (Table 3).

Table 3. Comparison of sub-dimensions of quality standards in healthcare services (QSH), and motivation of employees (ME) as per gender

\begin{tabular}{|c|c|c|c|c|c|c|}
\hline & Gender & $\mathbf{n}$ & $\mathbf{A M}$ & SD & $\mathbf{t}$ & $\mathbf{p}$ \\
\hline \multirow{2}{*}{ Economic Means } & Female & 101 & 4,5891 & ,48809 & -1.184 & ,238 \\
\hline & Male & 100 & 4,6675 & ,44954 & & \\
\hline \multirow{2}{*}{ Psychological and Social Means } & Female & 101 & 4,5010 & 2,52659 & -.590 &, 556 \\
\hline & Male & 100 & 4,5440 & (50699 & & \\
\hline \multirow{2}{*}{ Organizational and Managerial Means } & Female & 101 & $4,4,5149$ & "49348 & -.613 &, 540 \\
\hline & Male & 100 & 4,5575 & "49218 & & \\
\hline \multirow{2}{*}{ Motivation Total } & Female & 101 & 4,535 & 4,4635 & -.848 & 398 \\
\hline & Male & 100 & $4,4,590$ & ,4508 & & \\
\hline \multirow{2}{*}{ Managerial Processes } & Female & 101 & 4,0347 & "68628 & -.842 & 401 \\
\hline & Male & 100 & 4,1150 & ,66588 & & \\
\hline \multirow{2}{*}{ Educational Processes } & Female & 101 & 3,9228 & ב,73917 & -1.112 & ,267 \\
\hline & Male & 100 & 4,0360 & ,70346 & & \\
\hline \multirow{2}{*}{ Quality Standards in Health Care Services Total } & Female & 101 & 3,979 & "6590 & -1.055 & 293 \\
\hline & Male & 100 & 4,076 & ,6409 & & \\
\hline
\end{tabular}

In the comparison of sub-dimensions of quality standards in healthcare services (QSH), and motivation of employees (ME) as per age groups, significant difference was determined only in the scores of managerial processes dimension $(\mathrm{p}<0.05)$. According to this, the score of employees in age groups of 20-29 (3.83) was found to be lower than the employees in all the other age groups. (Table 4).

Table 4. Comparison of sub-dimensions of quality standards in healthcare services (QSH), and motivation of employees (ME) as per age groups

\begin{tabular}{|c|c|c|c|c|c|c|}
\hline & & $\mathrm{n}$ & AO & SS & $\mathbf{F}$ & $\mathbf{p}$ \\
\hline \multirow{6}{*}{ Economic Means } & $20-29$ & 54 & 4,5833 & .49048 & \multirow{6}{*}{1,570} & \multirow{6}{*}{,184 } \\
\hline & 30-39 & 60 & 4,6583 & .46251 & & \\
\hline & $40-49$ & 60 & 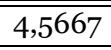 & .47583 & & \\
\hline & 50-59 & 19 & 4,8553 & (34677 & & \\
\hline & $\geq 60$ & 8 & 4,6250 & .51755 & & \\
\hline & Total & 201 & $4,4,6281$ & .46978 & & \\
\hline \multirow{2}{*}{ Psychological and Social Means } & $20-29$ & 54 & $4,4,4815$ & .51764 & \multirow{2}{*}{846} & \multirow{2}{*}{, 498 } \\
\hline & 30-39 & 260 & $4,4,5233$ & . .54255 & & \\
\hline
\end{tabular}




\begin{tabular}{|c|c|c|c|c|c|c|}
\hline & 40-49 & 60 & 4,4867 & .51337 & & \\
\hline & 50-59 & 19 & 4,6526 & .45628 & & \\
\hline & $\geq 60$ & 8 & 4,7500 & ".46291 & & \\
\hline & Total & 201 & 4,5224 & .51609 & & \\
\hline \multirow{6}{*}{ Organizational and Managerial Means } & $20-29$ & 54 & 4,5185 & .50435 & \multirow{6}{*}{,924 } & \multirow{6}{*}{451} \\
\hline & $30-39$ & 60 & 4,5333 & .49460 & & \\
\hline & $40-49$ & 60 & 4,4833 & .49332 & & \\
\hline & 50-59 & 19 & 4,6711 & .45684 & & \\
\hline & $\geq 60$ & 8 & 4,7500 & .46291 & & \\
\hline & Total & 201 & 4,5361 & .49207 & & \\
\hline \multirow{6}{*}{ Motivation Total } & $20-29$ & 54 & 4,528 & .4733 & \multirow{6}{*}{1,082} & \multirow{6}{*}{, 367} \\
\hline & 30-39 & 60 & 4,572 & .4632 & & \\
\hline & 40-49 & 60 & $4,4,512$ & .4599 & & \\
\hline & 50-59 & 19 & 4,726 & .3652 & & \\
\hline & $\geq 60$ & 8 & 4,708 & .4521 & & \\
\hline & Total & 201 & $\begin{array}{l}4,562 \\
\end{array}$ & .4569 & & \\
\hline \multirow{6}{*}{ Managerial Processes } & 20-29 & 54 & 3,8356 & .65689 & \multirow{6}{*}{2,964} & \multirow{6}{*}{, $021^{*}$} \\
\hline & 30-39 & 60 & 4,1021 & .64706 & & \\
\hline & 40-49 & 60 & $4,4,1542$ & .71543 & & \\
\hline & 50-59 & 19 & 4,3618 & .52687 & & \\
\hline & $\geq 60$ & 8 & 4,2031 & .69094 & & \\
\hline & 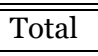 & 201 & "4,0746 & $\begin{array}{l}.67571 \\
\end{array}$ & & \\
\hline \multirow{6}{*}{ Educational Processes } & $20-29$ & 54 & 3,9519 & .60555 & \multirow{6}{*}{,193 } & \multirow{6}{*}{,942 } \\
\hline & 30-39 & 60 & 4,0167 & .67124 & & \\
\hline & 40-49 & 60 & 3,9967 & .78675 & & \\
\hline & 50-59 & 19 & 3,9579 & 1.00792 & & \\
\hline & $\geq 60$ & 8 & 3.8000 & .65900 & & \\
\hline & Total & 201 & 3,9791 & .72205 & & \\
\hline \multirow{6}{*}{$\begin{array}{l}\text { Quality Standards in Health Care Services } \\
\text { Total }\end{array}$} & $20-29$ & 54 & 3,894 & .5715 & \multirow{6}{*}{,887 } & \multirow{6}{*}{,473 } \\
\hline & 30-39 & 60 & 4,059 & ,6265 & & \\
\hline & 40-49 & 60 & 4,075 & ,7135 & & \\
\hline & (50-59 & 19 & 4,160 & ב,7422 & & \\
\hline & $\geq 60$ & 8 & $4,4,002$ & ,6148 & & \\
\hline & Total & 201 & 4,027 & ,6503 & & \\
\hline
\end{tabular}

In the comparison of sub-dimensions of quality standards in health care services (QSH), and motivation of employees (ME) as per educational statuses, significant difference was determined in the variables of quality standards in health care services (QSH) total, managerial processes (MP) and educational processes (EP) as it was $\mathrm{p}<0.05$. When differences were examined in multiple comparison tests;

In the dimension of quality standards in health care services (QSH) total, it was understood that the averages of graduates of postgraduate (4.37), a doctoral degree (4.05) and license degree $(4,08)$ were higher than the averages of graduates of high school $(3.839)$, secondary school $(3,829)$ and primary school $(3,371)$. Moreover, the average of graduates of primary school $(3,371)$ was found to be higher than the averages of graduates of high school $(3,839)$ and secondary school 
$(3,829)$. When all the dimensions were examined, it was observed that the educational level of individuals taking office at the hospital was high.

In the dimension of educational processes of quality standards in healthcare services (QSH), it was understood that the averages of graduates of postgraduate (4,30), a doctoral degree (3.96) and license degree $(4,04)$ were higher than the averages of graduates of high school (3.66), secondary school $(3,52)$ and primary school $(3,03)$. Moreover, the average of graduates of primary school $(3,03)$ was found to be higher than the averages of graduates of high school $(3,66)$ and secondary school $(3,52)$. When the dimension of educational processes of QSH was examined, it was observed that the educational level of individuals taking office at the hospital was high.

In the dimension of managerial processes of quality standards in health care services (QSH), it was understood that the averages of graduates of postgraduate $(4,430)$, a doctoral degree $(4,29)$ and license degree $(4,12)$ were higher than the averages of graduates of high school $(3,87)$, secondary school $(3,82)$ and primary school $(3,70)$. When the dimension of managerial processes of QSH was examined, it was observed that the educational level of individuals taking office at the hospital was high (Table 5).

Table 5. Comparison of sub-dimensions of quality standards in healthcare services (QSH), and motivation of employees (ME) as per education groups

\begin{tabular}{|c|c|c|c|c|c|c|}
\hline & & $\mathbf{n}$ & AO & SS & $\mathbf{F}$ & $\mathbf{p}$ \\
\hline \multirow{7}{*}{ Economic Means } & Primary School & 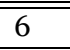 & 4,5000 & ,54772 & \multirow{7}{*}{2,268} & \multirow{7}{*}{,051 } \\
\hline & $\begin{array}{l}\text { Secondary } \\
\text { School }\end{array}$ & 14 & 4,3214 & ,46439 & & \\
\hline & "High School & 56 & 4,6875 & ,46282 & & \\
\hline & License Degree & 97 & 4,6675 & ,45174 & & \\
\hline & Postgraduate & 17 & 4,6618 & ,47550 & & \\
\hline & $\begin{array}{l}\text { Doctoral } \\
\text { Degree }\end{array}$ & 11 & 4,3864 & ,49198 & & \\
\hline & Total & 201 & 4,6281 & ,46978 & & \\
\hline \multirow{7}{*}{ Psychological and Social Means } & Primary School & 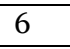 & 4,3333 & ,51640 & \multirow{7}{*}{2,012} & \multirow{7}{*}{, 079 } \\
\hline & $\begin{array}{l}\text { Secondary } \\
\text { School }\end{array}$ & 14 & 4,2000 & ,44376 & & \\
\hline & High School & 56 & 4,6036 & ,48765 & & \\
\hline & "License Degree & 97 & 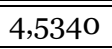 & "52577 & & \\
\hline & Postgraduate & 17 & 4,6353 & ,48598 & & \\
\hline & $\begin{array}{l}\text { Doctoral } \\
\text { Degree }\end{array}$ & 11 & 4,3455 &, 58028 & & \\
\hline & Total & 201 & 4,5224 & ,51609 & & \\
\hline \multirow{7}{*}{$\begin{array}{l}\text { Organizational and Managerial } \\
\text { Means }\end{array}$} & Primary School & 6 & 4,3333 &, 51640 & \multirow{7}{*}{1,460} & \multirow{7}{*}{,205 } \\
\hline & $\begin{array}{l}\text { Secondary } \\
\text { School }\end{array}$ & 14 & 4,3214 & ,46439 & & \\
\hline & "High School & 56 & 4,6116 & ,48832 & & \\
\hline & License Degree & 97 & 4,5361 & ,48946 & & \\
\hline & Postgraduate & 17 & 4,6471 & "49259 & & \\
\hline & $\begin{array}{l}\text { Doctoral } \\
\text { Degree }\end{array}$ & 11 & 4,3636 &, 50452 & & \\
\hline & Total & 201 & 4,5361 & ,49207 & & \\
\hline Motivation Total & Primary School & 6 & 4,389 & ,4907 & 2,126 & ,064 \\
\hline
\end{tabular}




\begin{tabular}{|c|c|c|c|c|c|c|}
\hline & $\begin{array}{l}\text { Secondary } \\
\text { School }\end{array}$ & 14 & 4,281 & ,4152 & & \\
\hline & High School & 56 & 4,634 & ,4556 & & \\
\hline & License Degree & 97 & 4,579 & ,4459 & & \\
\hline & Postgraduate & 17 & 4,648 & ,4636 & & \\
\hline & $\begin{array}{l}\text { Doctoral } \\
\text { Degree }\end{array}$ & 11 & 4,365 & ,4695 & & \\
\hline & Total & 201 & 4,562 & 4569 & & \\
\hline \multirow{7}{*}{ Managerial Processes } & Primary School & 6 & 3,7083 & ,43780 & \multirow{7}{*}{2,464} & \multirow{7}{*}{, $034^{*}$} \\
\hline & $\begin{array}{l}\text { Secondary } \\
\text { School }\end{array}$ & 14 & 3,8286 & ,79165 & & \\
\hline & High School & 56 & 3,8774 & ,70440 & & \\
\hline & License Degree & 97 & 4,1211 & ,65263 & & \\
\hline & Postgraduate & 17 & 4,4338 & ,60454 & & \\
\hline & $\begin{array}{l}\text { Doctoral } \\
\text { Degree }\end{array}$ & 11 & 4,2955 &, 52522 & & \\
\hline & Total & 201 & 4,0746 & ,67571 & & \\
\hline \multirow{7}{*}{ Educational Processes } & Primary School & 6 & 3,0333 & ,48028 & \multirow{7}{*}{3,591} & \multirow{7}{*}{, $004^{* *}$} \\
\hline & $\begin{array}{l}\text { Secondary } \\
\text { School }\end{array}$ & 14 & 3,5286 & 80997 & & \\
\hline & High School & 56 & 3,6607 & ,74191 & & \\
\hline & License Degree & 97 & 4,0454 & "69792 & & \\
\hline & $\begin{array}{l}\text { Postgraduate } \\
\end{array}$ & 17 & 4,3059 & ,60876 & & \\
\hline & $\begin{array}{l}\text { Doctoral } \\
\text { Degree }\end{array}$ & 11 & 3,9682 & ,53258 & & \\
\hline & Total & 201 & 3,9791 & ,72205 & & \\
\hline \multirow{7}{*}{$\begin{array}{l}\text { Quality Standards in Health Care } \\
\text { Services Total }\end{array}$} & Primary School & 6 & 3,371 &, 3761 & \multirow{7}{*}{2,916} & \multirow{7}{*}{, $015^{*}$} \\
\hline & $\begin{array}{l}\text { Secondary } \\
\text { School }\end{array}$ & 14 & 3,829 & ,7781 & & \\
\hline & High School & 56 & 3,839 & ,6807 & & \\
\hline & License Degree & 97 & 4,083 & ,6223 & & \\
\hline & Postgraduate & 17 & 4,370 &, 5852 & & \\
\hline & $\begin{array}{l}\text { Doctoral } \\
\text { Degree }\end{array}$ & 11 & 4,057 & ,4438 & & \\
\hline & Total & 201 & 4,027 & ,6503 & & \\
\hline
\end{tabular}

${ }^{* *} p<0.01{ }^{*} p<0.05$

In the comparison of sub-dimensions of quality standards in health care services (QSH), and motivation of employees (ME) as per experience groups, a significant difference was determined in the variables of quality standards in health care services (QSH) total, managerial processes (MP) and educational processes (EP) as it was $\mathrm{p}<0,05$. Significant differences were determined in the motivation of employees (ME) scale's total dimension, and in the dimensions of psychological and social means, and organizational and managerial means. When differences were examined in multiple comparison tests;

In the dimension of quality standards in health care services (QSH) total, it was understood that the averages of employees having an experience of 1-3 years $(4,13), 3-5$ years $(4,05)$ and 5 -10 years $(4,21)$ were higher than the averages of employees having an experience of 6 months -1 year $(3,64)$ 
and less than 6 months $(3,79)$. As the experience of the research's participants increase, it was observed that the dimension of the QSH total was high than the average at that extent.

In the dimension of educational processes of quality standards in health care services (QSH), it was understood that the averages of employees having an experience of 1-3 years (4,12), 3-5 years $(3,99)$ and 5 -10 years $(4,121)$ were higher than the averages of employees having an experience of 6 months -1 year $(3,61)$ and less than 6 months $(3,71)$. As the experience of the research's participants increase, it was observed that the dimension of the educational processes of QSH was high than the average at that extent.

In the dimension of managerial processes of quality standards in health care services (QSH), it was understood that the averages of employees having an experience of 1-3 years (4,13), 3-5 years $(4,21)$ and 5 -10 years $(4,30)$ were higher than the averages of employees having an experience of 6 months -1 year $(3,67)$ and less than 6 months $(3,71)$. As the experience of the research's participants increase, it was observed that the dimension of managerial processes of QSH was high than the average at that extent.

In the dimension of motivation of employees (ME) total, it was understood that the averages of employees having an experience of $1-3$ years $(4,64), 3-5$ years $(4,55)$ and 5 -10 years $(4,66)$ were higher than the averages of employees having an experience of 6 months -1 year $(4,19)$ and less than 6 months $(4,13)$. As the experience of the research's participants increase, it was observed that the dimension of motivation of employees total was high than the average at that extent.

In the dimension of psychological and social means, from among the sub-dimensions of motivation of employees (ME), it was understood that the averages of employees having an experience of 1-3 years $(4,60), 3-5$ years $(4,52)$ and 5-10 years $(4,69)$ were higher than the averages of employees having an experience of 6 months -1 year $(4,20)$ and less than 6 months $(4,12)$. As the experience of the research's participants increase, it was observed that the dimension of psychological and social means of motivation of employees was high than the average at that extent.

In the dimension of organizational and managerial means, from among the sub-dimensions of motivation of employees (ME), it was understood that the averages of employees having an experience of 1-3 years $(4,62), 3-5$ years $(4,52)$ and 5 -10 years $(4,63)$ were higher than the averages of employees having an experience of 6 months -1 year $(4,25)$ and less than 6 months $(4,13)$. As the experience of the research's participants increase, it was observed that the dimension of organizational and managerial means of motivation of employees was high than the average at that extent (Table 6).

Table 6. Comparison of sub-dimensions of quality standards in healthcare services (QSH), and motivation of employees (ME) as per experience groups

\begin{tabular}{|c|c|c|c|c|c|c|}
\hline & & $\mathbf{n}$ & AO & SS & $\mathbf{F}$ & $\mathbf{p}$ \\
\hline \multirow{6}{*}{ Economic Means } & $<6$ months & 18 & 4,4444 & ,48926 & \multirow{7}{*}{1,893} & \multirow{7}{*}{,113 } \\
\hline & $\begin{array}{l}6 \text { months - } 1 \\
\text { year }\end{array}$ & 30 & 4,5000 & ,49130 & & \\
\hline & 1-3 years & 77 & 4,7078 & ,44869 & & \\
\hline & $3-5$ years & 50 & 4,6250 & ,47716 & & \\
\hline & 5-10 years & 26 & 4,6731 & ,44592 & & \\
\hline & $\overline{T \text { Total }}$ & 201 & 4,6281 & ,46978 & & \\
\hline Psyco-Social Means & $\overline{l<6 \text { months }}$ & 18 & $4,4,1222$ & ,53088 & & \\
\hline
\end{tabular}




\begin{tabular}{|c|c|c|c|c|c|c|}
\hline & $\begin{array}{l}6 \text { months }-1 \\
\text { year }\end{array}$ & 30 & 4,2000 & ,53858 & \multirow{5}{*}{3,836} & \multirow{5}{*}{, $005^{* *}$} \\
\hline & 1-3 years & 77 & 4,6026 & , 49257 & & \\
\hline & 3-5 years & 50 & 4,5280 &, 51231 & & \\
\hline & 5-10 years & 26 & 4,6923 & ,44265 & & \\
\hline & Total & 201 & 4,5224 & ,51609 & & \\
\hline \multirow{6}{*}{$\begin{array}{l}\text { Organizational and Managerial } \\
\text { Means }\end{array}$} & $<6$ months & 18 & 4,1333 &, 48507 & \multirow{6}{*}{2,910} & \multirow{6}{*}{, $023^{*}$} \\
\hline & $\begin{array}{l}6 \text { months }-1 \\
\text { year }\end{array}$ & 30 & 4,2500 & ,47616 & & \\
\hline & 1-3 years & 77 & 4,6299 &, 48261 & & \\
\hline & 3-5 years & 50 & 4,5250 & , 49552 & & \\
\hline & 5-10 years & 26 & 4,6346 & ,46492 & & \\
\hline & Total & 201 & 4,5361 & ,49207 & & \\
\hline \multirow{6}{*}{ Motivation Total } & $<6$ months & 18 & 4,133 &, 4638 & \multirow{6}{*}{3,254} & \multirow{6}{*}{, $013^{*}$} \\
\hline & $\begin{array}{l}6 \text { months }-1 \\
\text { year }\end{array}$ & 30 & 4,197 & ,4496 & & \\
\hline & 1-3 years & 77 & 4,647 &, 4450 & & \\
\hline & 3-5 years & 50 & 4,559 &, 4545 & & \\
\hline & 5-10 years & 26 & 4,667 & ,4223 & & \\
\hline & Total & 201 & 4,562 & 4,4569 & & \\
\hline \multirow{6}{*}{ Managerial Processes } & $<6$ months & 18 & 3,7108 & ,56107 & \multirow{6}{*}{5,408} & \multirow{6}{*}{, $0000^{* *}$} \\
\hline & $\begin{array}{l}6 \text { months }-1 \\
\text { year }\end{array}$ & 30 & 3,6750 & ,64461 & & \\
\hline & 1-3 years & 77 & 4,1315 &, 68071 & & \\
\hline & 3-5 years & 50 & 4,2175 & ,61331 & & \\
\hline & 5-10 years & 26 & 4,3029 & ,66912 & & \\
\hline & Total & 201 & 4,0746 & ,67571 & & \\
\hline \multirow{6}{*}{ Educational Processes } & $<6$ months & 18 & 3,7111 & ,80139 & \multirow{6}{*}{3,444} & \multirow{6}{*}{,010* } \\
\hline & $\begin{array}{l}6 \text { months }-1 \\
\text { year }\end{array}$ & 30 & 3,6133 & 64953 & & \\
\hline & 1-3 years & 77 & 4,1299 & ,63059 & & \\
\hline & 3-5 years & 50 & 3,9920 & ,68638 & & \\
\hline & 5-10 years & 26 & 4,1231 & ,91578 & & \\
\hline & Total & 201 & 3,9791 & ,72205 & & \\
\hline \multirow{6}{*}{$\begin{array}{l}\text { Quality Standards in Healthcare } \\
\text { Services Total }\end{array}$} & < <6 months & 18 & 3,791 & ,6095 & \multirow{6}{*}{4,625} & \multirow{6}{*}{, $001^{* *}$} \\
\hline & $\begin{array}{l}6 \text { months }-1 \\
\text { year }\end{array}$ & 30 & 3,644 &, 5959 & & \\
\hline & 1-3 years & 77 & 4,131 &, 6133 & & \\
\hline & 3-5 years & 50 & 4,085 & ,5964 & & \\
\hline & 5-10 years & 26 & 4,213 & ב,7653 & & \\
\hline & Total & 201 & $4,4,027$ & ,6503 & & \\
\hline
\end{tabular}

${ }^{* *} p<0.01{ }^{*} p<0.05$

Hypothesis 1 (Accepted) The increase of quality standards in health ensures the increase of motivation of employees. The high level of quality standards in health positively and significantly affects the motivation of employees. 
It was observed that managerial processes of quality standards in health just affected in a positive direction the psychological and social means of motivation of employees, but that they didn't affect the economic means, and organizational and managerial means. It was determined that the education processes of quality standards in health didn't affect the motivation of employees by psychological and social means, but that they affected the same in a positive direction by organizational and managerial means. According to the demographic attributes of the participants of the research, it was determined that quality standards in health, and motivation of employees were being affected in a positive direction as their education and experiences increase. It was observed that the increase of the age of employees was positively affecting the managerial processes of quality standards in health, but that it wasn't affecting their motivation. It was determined that the gender of employees wasn't affecting the quality standards in health, and motivation of employees.

\section{Discussion}

For the quality standards to be successfully implemented, effective communication with the employees, training of employees, obtaining the ideas and opinions of employees, and participation of employees in the processes are intended 8 . By the implementation of these, success becomes inevitable, and each success obtained motivates the employees ${ }^{9}$. Considering health employees, it was observed that there is a relationship in positive direction between quality standards in health, and motivation of employees ${ }^{10}$. The increase of quality standards in health at healthcare organizations will increase the motivation of the healthcare professionals, and thus will ensure their more efficient and effective performance ${ }^{11}$. Quality in health care services is a process in which the required results are obtained for the patient, and in which the undesirable results don't arise ${ }^{12,13}$. By the results of this study, which was performed to determine the effect of quality standards in health care services on the motivation of employees, it was observed that quality standards in health statistically significantly and positively affect the motivation of employees ${ }^{14,15}$. The result of our research is compatible with the results of the research performed by Aydin (2014) with 57 employees working at a company operating in the pharmaceutical industry ${ }^{16-19}$. According to this study, quality standards in health are positively affecting the motivation of employees. Özer ve Kanbur (2012), by their study performed with 116 business managers, determined that total quality management was affecting the managers' content with economic, socio-psychological, and organizational and managerial means which encourages motivation ${ }^{17-19}$. In this study, it was observed that quality standards in health were positively affecting the psychological and social means (managerial processes of QSH), economic means (educational processes of QSH), and organizational and managerial means (educational processes of QSH) from among means of motivation ${ }^{18-19}$. The results of the study performed by Özer and Kanbur (2012) were compatible with the results of this study. When the results of the study were examined, it was determined that quality standards in health, and motivation of employees were being affected in a positive direction as the employees' education and experiences increased. It was observed that the increase of the age of employees was positively affecting the managerial processes of quality standards in health ${ }^{19}$. And it was observed that the gender of employees was not affecting any dimension in quality standards in health. Moreover, it was determined that the educational levels of the participants were high. In the educational and managerial processes of quality standards in health, it was observed that the employees having an experience of 1-10 years were more effective in the conduct of the QSH process compared to employees having an experience of 1 year and less than 6 months. In the psychological and social means, and organizational and managerial means dimensions of the total score of motivation of employees, 
it was determined that the motivation level of employees having an experience of 1-10 years was higher than the motivation level of employees having experience of 1 year and less than 6 months.

\section{Conclusion}

Considering health employees, it was observed that there is a relationship in positive direction between quality standards in health, and the motivation of employees. The increase of quality standards in health at healthcare organizations will increase the motivation of the healthcare professionals, and thus will ensure their more efficient and effective performance. This research is limited to the healthcare professionals working at two private hospitals in the province of Istanbul. For this reason, it is required to have different studies on this subject. It is suggested for similar studies to be performed at public hospitals, and in other provinces of Turkey. Moreover, in order to evaluate the effectiveness and efficiency of quality standards in health, apart from factors of motivation, the performance of researches such as the examination of relationships among organizational success, organizational performance and job satisfaction of employees will provide a significant contribution to the field. For improvement of relationships among increasing quality in the health sector, increasing the service quality, training of patients and strengthening the personnel, and strengthening the physicians and personnel in Turkey, I suggest the performance of studies with respect to these. As a result of these studies, I believe the point of view about people will improve in a positive direction. In order to maintain sustainable competition, and in order to exist in the future, strengthening the personnel at private and public healthcare organizations, and generating information regarding the new dimensions of personnel strengthening as the result of relating the referred factors are becoming obligatory. For this reason, the organizations should strengthen its personnel for taking precedence over their competitors, and for creating an advantageous status. The effects of other variables, as deeming the provision of health services, healthcare professionals, who directly affect the satisfaction level of patients benefiting from health services, and practices actualized for quality standards in health as determinants, are also considered as subjects required to be searched.

\section{REFERENCES}

1. Schuster MA, McGlynn EA, Brook RH. How good is the quality of health care in the United States? Milbank Q. 1988;76:517-64. doi:10.1111/1468-0009.00105.

2. Özyer K, Kanbur E. An empiric research on examination of course extending to motivation. Journal of World of Turks/Zeitschrift für die Welt der Türken. 2012;4(2):212-232.

3. Osland J, Kolb D, Rubin I. Organizational behavior: An experiential approach. 7 th ed. Upper Saddle River, NJ: Prentice Hall; 2000.

4. Uysal B, Yorulmaz M. Quality standards in health, and cognitive privacy. Selçuk University Journal of Social and Technical Researches. 2018;16:24-33.

5. Mosadeghrad AM. Healthcare service quality: towards a broad definition. Int $J$ Health Care Qual Assur. 2013;26:203-19. doi: 10.1108/09526861311311409.

6. Shahidzadeh-Mahani A, Omidvari S, Baradaran HR, Azin SA. Factors affecting quality of care in family planning clinics: a study from Iran. Int $J$ Qual Health Care. 2008;20:28490. doi: 10.1093/intqhe/mzno16. 
7. Lagrosen Y, Lagrosen S. The effects of quality management - a survey of Swedish quality professionals. International Journal of Operations, Production Management. 2005;25:940-52. doi: 10.1108/01443570510619464.

8. Mohammadi M, Mohammadi F, Zohrabi M. Quality management in Iran: Past experience, attitudes, and challenges. Proceedings of the 10th world congress for TQM. 2005, University of Manitoba, Canada.

9. Simbar M, Ahmadi M, Ahmadi G, Alavi-Majd HR. Quality assessment of family planning services in urban health centres of Shahid Beheshti Medical Science University. Int J Health Care Qual Assur. 2006;19:430-42.doi: 10.1108/09526860610680076.

10. Alexander JA, Weiner BJ, Griffith J. Quality improvement and hospital financial performance. Journal of Organizational Behavior. 2006;27:1003-29. doi: 10.1002/job.401.

11. Parasuraman A, Zeithaml VA, Berry LL. A conceptual model of service quality and its implications for future research. Journal of Marketing. 1985;49:41-50. doi:10.2307/1251430.

12. Glickman SW, Baggett KA, Krubert CG, Peterson ED. Promoting quality: The health-care organization from a management perspective. Int J Qual Health Care. 2007;19:341-8. doi: 10.1093/intqhe/mzmo47.

13. Mosadeghrad AM. Towards a theory of quality management: an integration of strategic management, quality management and project management. International Journal of Modelling in Operations Management. 2012;2:89-118. doi:10.1504/ijmom.2012.043962.

14. Aghamollaei T, Zare SH, Bodat A. Patients perception and expectation about healthcare services in Bandarabas healthcare centres. Journal of Hormozgan University of Medical Sciences. 2007;11:173.

15. Aydin C. Effect of Total Quality Management on Motivation of Employees: An Implementation at Pharmaceutical Sector [master's thesis]. Istanbul, Türkiye: Maltepe University, Institute of Social Sciences; 2014.

16. Hall JE. Pluralistic evaluation: a situational approach to service evaluation. $J$ Nurs Manag. 2004;12:22-7. doi: 10.1111/j.1365-2834.2004.00389.x.

17. Mehrdad R. Health System in Iran. Japan Medical Association Journal. 2009;52:73.

18. Mohammadi A, Shoghli AR. A survey on quality of primary health care in Zanjan district health centres. Journal of Zanjan University of Medical Science. 2008;16:89-100.

19. Amabile T. M. Motivation and creativity: Effects of motivational orientation on creative writers. Journal of Personality and Social Psychology. 1985;48(2):393-399. 